instrument for plant applications were its great speed (three components could be estimated in less than $1 \mathrm{~min}$ ) and its high sensitivity. Applications had included such things as: (1) estimation of $0-50$ p.p.m. of acetylene in benzene; (2) control of phthalic anhydride production; (3) determination of hydrochloric acid, chlorine and phosgene from 'Fluolube' on 'Teflon'; (4) determination of hydrogen in water in the range 0-5 p.p.m.; this estimation could be carried out in 5 min on a $50-\mu l$. sample; (5) heart cut analysis of ethylene; (6) cascade control of distillation columns. $\mathrm{He}$ concluded by saying that generally a pay-off time of one year could. be considered a good: application of instrumentation.

C. D'OyLY-Watkins

\title{
PLACE OF BIOCHEMISTRY IN THE NEW UNIVERSITIES
}

$\mathrm{A}^{\mathrm{T}}$

The Middlesex Hospital Medical School on April 16, A the Biochemical Society held an evening discussion on "The Place of Biochemistry in the New Universities", a topic which aroused considerable interest and not a little feeling. In framing the discussion it had been agreed not to limit it strictly to the new universities but to include all universities in which biochemistry had only recently been introduced or was about to be taught.

Sir Rudolph Peters took the chair and, in the course of his opening remarks, pointed out that nowadays many aspects of biochemistry masqueraded under other titles. The new term 'molecular biology' had been introduced by Astbury and was, perhaps, valuable for getting money, but the claim that biochemistry only dealt with small molecules was just not true-we had always dealt with substances like proteins. With the present ramifications of biochemistry it was especially pertinent to discuss its role in the new universities.

Prof. R. A. Morton (Liverpool), under the title of "Biochemistry-Past and Present", traced the development of biochemistry with special reference to universities where the subject is now firmly established. The first department of biochemistry in Great Britain was founded at Liverpool in 1906, the inspiration of the department and of biochemistry in general at that time being derived from work on vitamins and nutrition. This and other departments were first set up in faculties of medicine, for it was from this direction that the need for teaching and research first arose. Very few honours courses in science faculties were started before 1939, but since the War the number of such courses had multiplied rapidly so that to-day most recruits to the subject have been trained as biochemists.

Over the years, the courses for medical, dental and veterinary students have changed and continue to do so. Although in the teaching, applications are not forgotten, they are subordinated to the need to expound the basic principles of biochemistry so that, for example, the clinical aspects of the subject come later from specialists.

Prof. Morton stressed that the biochemist should be competent in chemistry but must also have biological training and insight. Much had been achieved in the past, and no doubt would be in the future, by those who had detected, isolated and determined the structure of metabolites. Theories, for example, of photosynthesis or oxidative phosphorylation could be elegant even with an incomplete roll-call, but truer theories follow a full muster of the molecular species engaged-whether in biosynthesis or enzymatic mechanisms.

Biochemistry is now a central part of many curricula in biology. The sharp boundaries between sciences have gone; trespassing invokes only a shrug and territories are 'invaded' without apology. Chemistry, biochemistry and microbiology interpenetrate, and terms like genetics, biochemical pharmacology, neurobiochemistry and biochemical systematics all point to unification within diversity. This calls for psychological readjustment and reconstruction of teaching, organization and administration, on a scale easier to realize in a new university than an established one. There must be flexibility, perhaps, especially in M.Sc. courses. Prof. Morton emphasized that there is, however, a hard core of biochemistry which cannot safely be watered down.

In a period of expansion the penury of the past was easily forgotten, but it may be more difficult to sustain the peculiar excellence which raises university studies above the trivial.

In the subsequent discussion, Prof. J. N. Davidson (Glasgow) pointed out that biochemistry has tended always to suffer from being a hybrid subject. It grew up under the wing of physiology in most universities (occasionally under pathology) and only within recent years has begun to lead an adult independent life as a scientific discipline in its own right, rather than merely as a subdivision of some other subject. However, there are now disturbing trends. The chemists, who used to despise it, are now beginning to realize its importance and are tending to say that biochemistry should certainly be developed in all universities, but only as part of the chemistry department.

The biologists are belatedly taking an interest in biochemistry and are tending to follow the same unfortunate course as the chemists. By showing less interest in taxonomy and ecology and a greater interest in cell biology, they have realized that they cannot go very far in any biological discipline without biochemical help and they are therefore tending to say biochemistry must certainly be developed, but only as a part of a biological department.

Prof. Davidson went on to say that he was all in favour of breaking down barriers between sciences and of having the utmost collaboration between representatives of different disciplines, but was utterly opposed to the trend that biochemists may develop into mere laboratory assistants helping 'big brother biologist' to solve his problems.

Prof. E. A. Dawes (Hull) then presented the results of a survey he had made on present and future developments in Britain with particular reference to the place of biochemistry in the development of biological sciences in the new universities. There are seven new universities in England of which five have either planned or already initiated biological studies, and a sixth has it under active consideration. In Scotland, at the new University of Strathclyde, existing biology departments of the Glasgow Royal College of Science and Technology are to become part of a School of Biological Sciences, housed together in a separate new building and offering honours degrees in biochemistry, food science, biology, microbiology and general biological sciences.

The development of biological sciences in the new English universities has, without exception, followed the suggestion of the ad hoc Committee of the Royal Society (Ann. Rep. Advisory Council on Scientific Policy, 1961-62, H.M.S.O., 1963) that multi-professorial departments be created and under the one roof a variety of different biological disciplines be represented. East Anglia, at present, is the only school to have started teaching along these lines; Sussex and York both commence 
operations in October 1965, while Kent expects to do so in 1966 .

At Sussex advanced teaching and research are being arranged round a number of research groups each headed by a senior member of staff; the units at present envisaged include animal physiology, biochemistry, microbiology and plant physiology, and the research activities of most of them will be strongly biochemical in outlook. The threo-year honours course in biology will precede a fourthyear course of advanced study leading to an M,Sc. degree. At York fairly close co-operation between the departments of biology and chemistry is planned and the three-year honours course in biology will include specialization in the third year; biochemistry may be selected as one of the topics for this. Clearly, courses in the new departments are in the process of evolution and present information is of a provisional nature. It was evident, however, that belief in the necessity for a fourth-year M.Sc. course was universal in the new universities offering degrees in biology. To conclude, Prof. Dawes mentioned the newly created professorial departments in universities which do not have a medical school-Leicester, Southampton and Hull-and gave a brief deseription of the honours course in his own Department which includes a one-year course in cell biology, two years of chemistry and biochemistry in all three years.

In discussion, Prof. J. F. Sutcliffe amplified the plans for Sussex and emphasized the importance of the biochemistry unit to their scheme. Other speakers expressed misgivings on the brevity of the basic chemistry courses in many of the biological sciences syllabuses and pointed to the flimsy foundations on which the biochemical content of the course would have to be built. The chairman stressed that all biochemists should be taught to work with small amounts of substances.

Prof. H. L. Kornberg (Leicester) outlined the development of biochemistry within the framework of a three-year course leading to a degree in cell biology, and discussed the reasons for this approach rather than the more conventional honours course in biochemistry. At Leicester it was felt that, at the undergraduate level, biochemistry might be most effective as the central theme of an interdepartmental degree course jointly planned and executed chiefly, if not exclusively, by spocialists in biochemistry, genetics and physiology, but that chemistry to an advanced level, and other physical and biological specialities to less-advanced levels, would also form indispensable parts of the degree structure. Such a course would provide graduates suitable for teaching at the secondary modern school level, Civil Service experimental officer grade, or the equivalent level in hospital or industry. More able students would take one-year M.Sc. courses in the particular speciality that has aroused their interests and this would be a prelude to the orthodox three-year period leading to a Ph.D. The flexibility which this proposed course, planned for 1967, would confer, by virtue of the wide biological interests of the academic staff concerned, was emphasized.

Prof. Kornberg then described plans for the new School of Biology at Leicester, which, with more than $90,000 \mathrm{sq}$. ft. of usable space, will house not only all the existing biological science departments but possibly also biological specialities as yet unborn. A department of genetics has recently been established and similar developments in general physiology are to occur, while the appointment of Dr. E. R. Redfearn to a second chair of biochemistry at Leicester had just been made.

The development of biological chemistry in the University of Manchester was described by Prof. A. J. Birch. An honours school of biological chemistry was established in 1961 in the Faculty of Science with studies extending over three years and with considerable emphasis on chemistry and biology. At present, this is achieved by exclusion of biochemistry from the first-year courses, and the intermediate examination at the end of the first session includes chemistry, physiology and either botany or zoology. The first two terms of the second year are divided equally between chemistry and biochemistry, both of which are included in the Part I examination held at the end of the Easter vacation of the second session. Biochemistry occupies the whole of the students' time during the summer term of the second year (this being a full teaching term) and throughout the third year, with the exception that during the third year students attend short ancillary courses chosen from a wide range.

A full tutorial system is operated during the summor torm of the second year and throughout the third year, and less frequently in the earlier parts of the course. It is hoped in future to extend the full tutorial systom to all three years. Further developments planned for the future include an introductory biochemical course in the first year and it is hoped that a single, fully integrated course in biology may be established.

In planning the courses for the new honours degree, the aim has been to give students a thorough understanding of the chemical and biological bases of the subject and a good appreciation of general biochemistry without emphasizing any one specialized aspect. Dr. G. R. Barker elaborated on some aspects of the course.

The final speaker was Prof. T. A. Bennet-Clark (Norwich), who discussed the role of biochemistry within a school of biology and described developments at East Anglia, where a special feature is being made of the biological sciences. Biochemistry is fundamental and must be incorporated in the courses, but this could only be achieved by elimination of dead wood from the more classical aspects of the biological parts of the curriculum. A critical problem is that of recruitment, for the ideal aspirant should have a good background of mathematics, physies and chemistry in addition to his biology; this poses almost insuperable difficulties in the schools and forces the university school of biology to teach in the first year appropriate aspects of mathematics and physics.

A three-year undergraduate course is operated at Norwich which provides during the first two years, in addition to chemistry, mathematics and physics, a background having a general physiological and genetical basis. The third year permits specialization in which three options are selected from a present list of eight, of which (1) biochemistry and (2) biophysics and biophysical chemistry are two. A fourth-year M.Sc. course permits further specialization: a course in biophysics is run by Prof. J. Dainty and, in the future, a course in food science will be available. Prof. Bennet-Clark made the point that a three-year first degree course is by no means an adequate training for any career and hence the desirability of having a fourth-year M.Sc. course.

Sir Rudolph Peters then declared the meeting open for general discussion and some lively comments ensued. Concern was expressed that the plans for the new universities did not include strong biochemistry departments in which the teaching was securely based on chemistry. Latent fears for the emergence of a breed of 'tame biochemists' were in evidenco.

Dr. G. R. Barker aroused much interest and support for his proposal that a new advanced-level subject 'Physics with Mathematics' should be instituted by the examining boards. Such a paper would go a long way towards solving the problem of university entrance requirements for the biological sciences. The meeting passed a resolution that the Committee of the Biochemical Society consider whether the Society might approach the examining boards in this connexion. Prof. Morton said how important it was that faith should be kept with the school teachers so that they knew precisely what the university biologists wanted of their pupils.

The meoting was universally adjudged to have been a timely and instructive one, and the large attendance reflected the widespread interest in developments in the new universities.
E. A. DAwES 